\title{
Impact of Effective Training Program, Job Satisfaction and Reward Management System on the Employee Motivation with mediating role of Employee Commitment
} Shahid Hussain MS Scholar, Department of Business Administration National College of Business Administration \& Economics, Bahawalpur, Pakistan Muhammad Rizwan Lecturer, Department of Management Sciences, The Islamia University of Bahawalpur, Pakistan Email: rizwan.arshad@iub.edu.pk

\section{Muhammad Sajjad Nawaz}

MS Scholar, Department of Business Administration

National College of Business Administration \& Economics, Bahawalpur, Pakistan

Waseem ul Hameed

MS Scholar, Department of Business Administration

National College of Business Administration \& Economics, Bahawalpur, Pakistan

Muhammad Rizwan

MS Scholar, Department of Business Administration

National College of Business Administration \& Economics, Bahawalpur, Pakistan

Accepted: September 13, 2013 DOI: 10.5296/jpag.v3i3.6222 


\title{
M Macrothink
}

\begin{abstract}
This study examines the relationship between independent variables Effective Training Programs, Job Satisfaction and Reward Management system on dependent variable Employee Motivation with the Intervening role of Employee Commitment. Employees of the four Organizations Universities, Colleges, Schools and Banks were taken as sample of the study. Self-designed questionnaire used for collection of data. 150 questionnaires were distributed among the above mentioned organizations and 150 were returned, so the response rate was $100 \%$. The data was analyzed through multiple regression technique. Significance level of the testing was 0.01 and 0.05 . The result concludes that there is a significant positive relationship between effective training program, job satisfaction, reward management system and Employee motivation with the intervening role of employee commitment.
\end{abstract}

Keywords: Employee Motivation, Employee Commitment, Job Satisfaction, Rewards, Training, Regression

\section{Introduction}

Every organization faced the most important issue of employee motivation. It is one of the major aspects of every manager's task to motivate the employees for the work. Everyone should know that if a worker having extraordinary skills but he is not motivated than the achievement will be zero. Subordinates will not follow the manager if they are not motivated. That is why a reasonable motivation use is necessary. So, this studies also targeting the employee motivation within the employees of an organization.

Motivation consists of a long history involving the needs of employees and motivates them (Alderfer, 1969; Maslow, 1954; McClelland, 1961). In 1970s and the start of 1980s, motivation was point of interest but not enough research found in last 15 years. Work motivation and need fall within three categories in the research of 1990s. These categories were checking of the attributes which cause of individual motivation, for the purpose of achievement finding of need and on work ethic. Capability and motivation is one of the functions of employee performance. And one important task of managers is that to motivate employees in such a way that they perform best according to their abilities (Moorhead \& Griffin, 1998).

The objective of this study is to examine the effect of effective training program, job satisfaction and reward management system on employee motivation with considering the employee commitment.

Job satisfaction is one of the charming emotional states from the experience of the job. Generally it tells the feeling and thinking of an employee about the job. Employees having positive thinking always take part actively in their duties but the employees having negative feeling cannot take part actively in their duties.

Improvement in achieving the goals need training which is necessary and it should be achieved by the members of organization. Training decrease the degree of frustration brings 
by the demand of working and handles the employees who are lacking the skills (Chen et al., 2004). It can be determined that how efficiently it fulfills the expectation and it also represented by the work, opportunities for promotion and supervision, all these are one of the major features of job (Luthans, 1998).

System which contain the policies, practices and the process for the rewards to employees on the basis of participation, artifice and capabilities of employees are called the reward management system. Philosophy, strategies as well as policies progress the reward management system. It also includes the process, structure as well as the procedure which gives the standard to provide pays and other rewards. Quantity, quality, timelines and attendance are the employee's performance. Employees give all of these full when they know that they will be rewarded. There are also some other factors which effect the performance of employees such as condition in which they work, relationship between the employee and supervisor/manager/employer, security of job, opportunities for the development as well as the procedure developed by the organization for reward system. In all of these factors reward is most important factor for the performance and motivation of employees. Collection of different processes and effect of these processes shape the behavior for achievement of specific goals of an organization (Baron, 1983).

\section{Past Literature}

In the situation of present competition organizations have to increase their land resources. And the leaders of each organization always should be aware of different factors and the internal changes can effect on the different aspect which are required for high performance. All of this can be achieved my encouraging the employees to work together.

Motivation is one of the instruments which give the permission for each employee to work with their best skills (Gellerman, 1992). It allows the people to pay intention just on mind and work effectively as much as possible. Achievement of employees own goals and the goals of organization depends upon the inside forces (Lindner, 1998). Motivation helps to shows the hidden abilities of employee and gives the higher satisfaction as well as makes them successful.

Motivation is necessary for the survival and employees need to change workplace frequently. Employees who are motivated always take part in the survival of organization. Managers should know the factors which take part to motivate the employees to increase the performance. Employees should help the managers to know about the motivation factors and managers should design system of rewards which can motivate the employees.

One of the important points in study of workplace is the identification of factors which influence the quality as well as quantity of the performance of the employees. Managers of the organization should develop assumption to make performance better on the routine bases. Structure and characteristics of task also influence the performance of the employees. Characteristics of task include, it possible for employee to work independently or not, task is clearly defined or not, and employee will be rewarded for hard work or not (Chang, et al, 1996) 


\section{Effective Training Program and Employee Commitment}

"Effective training program defined as the planned involvement that is intended to improve the determinants of individual performance of job." (Chiaburu and Tekleab, 2005, p, 29). Commitment is a useful gain from relationship of employees because the employee turnover decreases bases on the ratio of contribution (Gaertner \& Nollen, 1989). Cost linked with company membership and rewards is known as commitment (Reichers, 1985).

Influence of training on employee motivation, satisfaction of employees and commitment of employees not get more intention as it should get. There was only few research studies in which shows the intervention in training to effect the attitude of employees. The purpose of the training should to enhance the commitment of the employees (Lang, 1992). Basically, commitment is linked with the human resource management practices. These human resource management practices included the promotion of employees, opportunities which were provided in training and security of employment (Gaertner and Nollen, 1989).

The above whole discussion was on the benefits and effects of employee training on the outcomes of the employees in the era for high turnover. Cheramie et al. (2007), tells that the people who always change their jobs they earn more salary as compared to the other people. That is why employers are discouraged to rain the employee because they learn just for their own development not for the benefit of organization on the expense of organization. These arguments lead to the following hypotheses:

\section{Hypothesis 1: Effective training program leads to Employee commitment}

\section{Job satisfaction and Employee commitment}

"Job satisfaction is a result of employee's perception of how well his job provides those things that are viewed as job or job experience" (Locke, 1976)

It is observed that employee commitment and desirable outcomes (e.g. performance, satisfaction of job, adaptness) have a relationship which is positive and strong (Angle \& Perry 1981; Hunt, Chonko\& Wood 1985; Mowday, Porter \&Dubin 1974). Aamodt (2007) tells that the employees who are satisfied are more committed, and the employees having satisfaction and commitment are more connected with work, having less turnover, having good performance, timely start the work and behave according to the organization help. A correlation empirically developed satisfaction of job, commitment of employees and retention has been strong (Kotze and Roodt, 2005).

There are other factors which most likely influence employee commitment, these factors include type of work, liability level in job, verities in job, desirability of work, quality of relationship such as social, independence in the job, opportunities for the development of employee and career enhancement (Riggio 2009), reward system as well as the compensation system of the organization. Following hypotheses was generated from these arguments:

Hypothesis 2: Job satisfaction leads to Employee commitment 


\section{Reward management system and employee commitment}

Reward management system is an instrument having the ability to grasp, hold and motivate the good potential employees and in response good level of performance meet (Barber and Bretz, 2000). This literature on employee performance shows wide range individuals and their features. Past experience of employees effects the innovation (Scott and Bruce, 1994), personality and some other factors like age, background of education and experience of past research and development (Roberts, 1991 and Rothwell, 1992). In case of organizational antecedents, research and development expenditure (Hadijimanolis, 2000), collaboration with outsider technology supplier, leaders affect (Hage and Dewar, 1973), and system of rewards (Eisenberger and Cameron, 1996; Janssen, 2000; Mumford, 2000) are factors which affect the innovative performance of employees. Well managed reward system can motivate the employees but ineffective reward system cannot motivate the employees. Reio\&Callahon (2004) tells that both rewards intrinsic and extrinsic motivate the employees and in case higher performance achieved. Other rewards like social rewards promote to develop the trust and interest to achieve the goals of an organization (Burke, 2002). Employees who think that their supervisor is helpful they become more dedicated to employer (Adeyemo \& Aremu, 1999). When the supervisor support the employees and behave according to the objectives and employees emotions than trust developed in employees and they follow the behavior of their supervisor (Burke, 2002). According to these arguments following hypotheses has been derived:

Hypothesis 3: Reward management system leads to Employee commitment

\section{Employ commitment and Employee motivation}

Motivation is the factor which enables the employees to execute expertly (Van Knippenberg, 2000). Motivation is the collection of dissimilar processes and these processes influence and express the behavior to fulfill certain goal (Baron, 1983).

Motivation is the set of processes which includes the push and pull forces and these forces gives the power to any action to accomplish certain goal (Baron (1983). It is the collection of different factors which develops positive feelings and gives a positive attitude among the employees and these factors was related to task. There was also some factors which did not directly related to job but depends upon the condition of job and these factors were primarily involved in negative behavior and unhappiness feelings. Combination of three forces valence, instrumentality and expectancy is called motivation and the fulfillment of these three forces is the sign of employee motivation (Vroom, 1964). Vroom (1964) tells that firstly they have to give importance to behavioral outcomes; secondly they will receive some outcomes if they behave in a specific way. At last, they have to accept that, they have the ability to do such behave which will help them to accomplish the specific goals.

Hypotheses 4: $\quad$ Employee commitment leads to the employee motivation 


\section{Research Model}

(IV)

(IVV)

(DV)

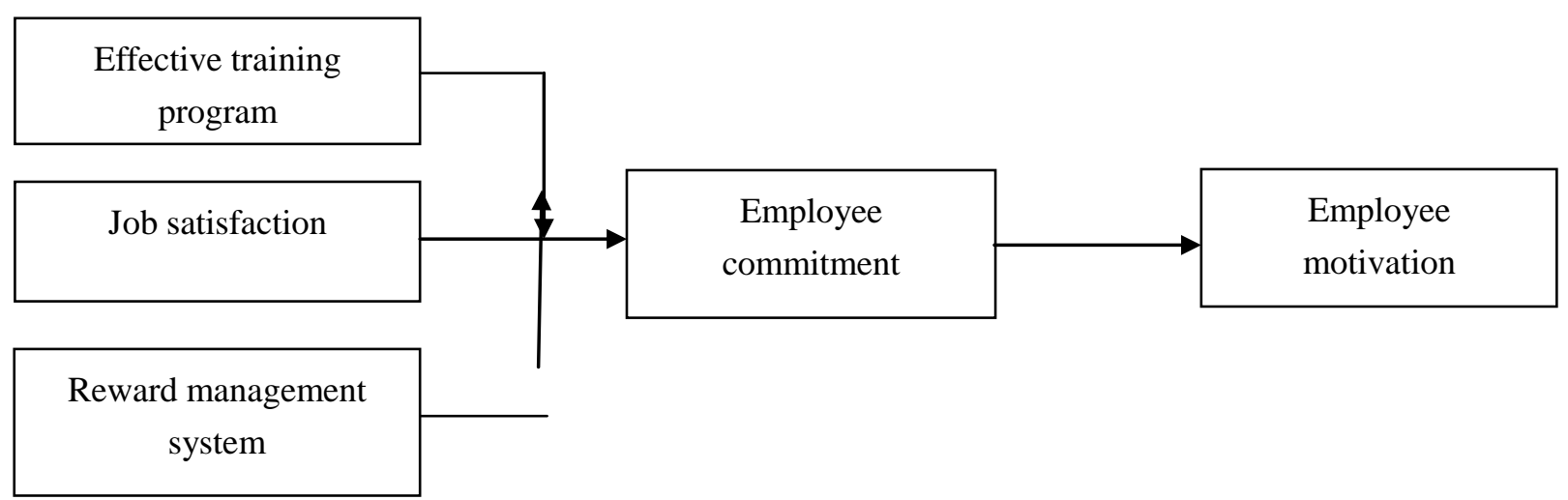

\section{Research Methodology}

As this study examines the impact of Independent variables Effective training programs, Job satisfaction and Reward management system on Dependent variable Employee Motivation with the help of Intervening variable of Employee commitment.

\subsection{Sample/Data}

Using convenience method of sampling, 150 self-administered questionnaires were distributed among the employees of schools, University and Banks in Bahawalpur. All questionnaires were reverted, so the response rate was $100 \%$.

Self-Designed questionnaire has been established for data collection. Self-designed questionnaire was divided into two parts; one holding socio-demographic questions and the second part holding questions associated to variables that are Effective Training Programs, Job Satisfaction, Reward Management System, Employee Commitment and Employee Motivation.

\subsection{Instruments and Measurement Scales}

The survey instrument encloses two sections. Section 1 includes different personal and demographic variables. This section will attain the respondent's information about gender, age, income, education and status.

Section 2 includes the suppressed variables that are important in the current study. These variables include Effective Training Programs, Job Satisfaction, Reward Management System, Employee Commitment and Employee Motivation. This section of the study is established based on the past literature and already used questionnaires (Table 1).

The scales of the study were adopted from the prior literature and published studies. 
Table1: Scales of the Study:

\begin{tabular}{|c|c|c|c|}
\hline No. & Variables & Items & \\
\hline 1 & $\begin{array}{l}\text { Effective } \\
\text { Training } \\
\text { programs }\end{array}$ & $\begin{array}{l}\text { 1. My company provides me the } \\
\text { opportunity to improve my skills } \\
\text { 2. My company frequently arranges } \\
\text { training programs for the } \\
\text { employees } \\
\text { 3. Doing job in this company will } \\
\text { benefit us in the future } \\
\text { 4. I am satisfied with the training } \\
\text { and development provided by } \\
\text { the company }\end{array}$ & Cheramie et al. (2007) \\
\hline 2 & $\begin{array}{l}\text { Job } \\
\text { Satisfaction }\end{array}$ & $\begin{array}{l}\text { 1. Overall, I am pleased with my } \\
\text { work } \\
\text { 2. My current work situation is } \\
\text { not a major source of frustration } \\
\text { in my life } \\
\text { 3. My work in this practice has met } \\
\text { my expectations } \\
\text { 4. If I had it to do it all over again, } \\
\text { I'd still choose to work where I } \\
\text { do now }\end{array}$ & Lindner, 1998 \\
\hline 3 & $\begin{array}{l}\text { Reward } \\
\text { Management } \\
\text { System }\end{array}$ & $\begin{array}{l}\text { 1. I am satisfied with the incentives } \\
\text { provided by the organization to } \\
\text { the employees } \\
\text { 2. The reward management system } \\
\text { will influence employees' } \\
\text { performance } \\
\text { 3. Financial incentives motivates } \\
\text { me more than non-financial } \\
\text { incentives } \\
\text { 4. The salary increments given to }\end{array}$ & Janssen, 2000 \\
\hline
\end{tabular}




\begin{tabular}{|c|c|c|c|}
\hline & & $\begin{array}{l}\text { employees who do their jobs } \\
\text { very well motivates them }\end{array}$ & \\
\hline 4 & $\begin{array}{l}\text { Employee } \\
\text { commitment }\end{array}$ & $\begin{array}{l}\text { 1. I am happy with my work } \\
\text { 2. I enjoy working in this } \\
\text { organization } \\
\text { 3. I recommended this } \\
\text { organization to others as a good } \\
\text { place to work } \\
\text { 4. In General, I like my job }\end{array}$ & Lindner, 1998 \\
\hline 5 & $\begin{array}{l}\text { Employee } \\
\text { Motivation }\end{array}$ & $\begin{array}{l}\text { 1. I feel a sense of personal } \\
\text { satisfaction when I do this job } \\
\text { well } \\
\text { 2. My opinion of myself goes } \\
\text { down when I do the job badly } \\
\text { 3. I take pride in doing my job as } \\
\text { well as I can } \\
\text { 4. I feel unhappy when my work is } \\
\text { not up to my usual standard } \\
\text { 5. I like to look back at a day's } \\
\text { work with a sense of a job well } \\
\text { done } \\
\text { 6. I try to think if ways of doing my } \\
\text { job effectively }\end{array}$ & Lindner, 1998 \\
\hline
\end{tabular}

\subsection{Procedure}

The questionnaire was circulated among 150 respondents in Bahawalpur, Sadiqabad and Ahmad pur east. These respondents are selected based on the criteria above stated. Before giving the questionnaire, the purpose of study and questions were explained to the respondents so they can easily fill the questionnaire with related responses. After collecting the completed questionnaires, these questionnaires were implied and arrived into SPSS sheet for more analysis.

\subsection{Reliability Analysis}

Overall Cronbach's alpha of Employee Motivation questionnaire items were 0.810 that is more than acceptable and suggested value 0.50 by Nunnally (1970) and 0.60 by Moss et al. 
(1998). This shows that all the 22 items were reliable and valid to measure the Employee Motivation.

Table 2: Reliability of Measurements Instrument

\begin{tabular}{|l|l|l|}
\hline scales & Items & Cronbach's Alpha \\
\hline Effective Training Program & 4 & .773 \\
\hline Job Satisfaction & 4 & .635 \\
\hline Reward Management System & 4 & .692 \\
\hline Employee Commitment & 4 & .801 \\
\hline Employee Motivation & 6 & .883 \\
\hline
\end{tabular}

\section{Results and Analysis}

\subsection{Profile of the Respondents}

Personal and demographic information for instance gender, age, income, education level, status are presented in the following table (Table 3).

Table 3: Profile of the Respondents

\begin{tabular}{|l|l|l|l|}
\hline & Category & Frequency & Percentage \\
\hline variables & & & \\
\hline Gender & Male & 113 & 75.3 \\
& Female & 37 & 24.7 \\
\hline \multirow{3}{*}{ Age } & $15-20$ Years & 1 & .7 \\
$20-25$ Years & 31 & 20.7 \\
& $25-30$ Years & 38 & 25.3 \\
& $30-35$ Years & 31 & 20.7 \\
\hline
\end{tabular}




\begin{tabular}{|c|c|c|c|}
\hline & $\begin{array}{l}35-40 \text { years } \\
\text { Above } 45 \text { Years }\end{array}$ & $\begin{array}{l}27 \\
22\end{array}$ & $\begin{array}{l}18.0 \\
14.7\end{array}$ \\
\hline Income /Rs. & $\begin{array}{l}\text { Below } 15000 \\
15000-25000 \\
25000-35000 \\
35000-45000 \\
45000-55000 \\
\text { Above } 55000\end{array}$ & $\begin{array}{l}12 \\
57 \\
49 \\
25 \\
4 \\
3\end{array}$ & $\begin{array}{l}8.0 \\
38.0 \\
32.7 \\
16.7 \\
2.7 \\
2.0\end{array}$ \\
\hline Education & $\begin{array}{l}\text { Matriculation } \\
\text { Inter } \\
\text { Bachelor } \\
\text { Master } \\
\text { MS/M. Phil } \\
\text { PhD }\end{array}$ & $\begin{array}{l}10 \\
13 \\
25 \\
83 \\
17 \\
2\end{array}$ & $\begin{array}{l}6.7 \\
8.7 \\
16.7 \\
55.3 \\
11.3 \\
1.3\end{array}$ \\
\hline Status & $\begin{array}{l}\text { Student } \\
\text { Employed } \\
\text { Businessman } \\
\text { Unemployed } \\
\text { Housewife }\end{array}$ & $\begin{array}{l}4 \\
143 \\
1 \\
2 \\
0\end{array}$ & $\begin{array}{l}2.7 \\
95.3 \\
.7 \\
1.3 \\
0\end{array}$ \\
\hline
\end{tabular}

\subsection{Hypothesis Testing}

\subsubsection{Effective Training Program and Employee Commitment}

According to the results of the study, the both variables of Effective Training Program and Employee Commitment has a significant positive relationship with $(\beta=0.578)$ and $(p<0.01)$. 


\section{Macrothink}

That means the Effective training programleads to the Employee Commitment more than $57 \%$. Results of the present study confirm the H1.

\subsubsection{Job satisfaction and Employee commitment}

The regression results of the study check the significant positive relationship between Job satisfaction and Employee commitment with $(\beta=0.378)$ and $(p<0.01)$. According to these results, Job Satisfaction leads to Employee Commitment almost 38\%. This result of the study authenticates $\mathrm{H} 2$.

\subsubsection{Reward management system and Employee commitment}

According to the regression results of the study that there are significant positive relationship between Reward management system and employee commitment with $(\beta=0.339)$ and ( $\mathrm{p}<0.01)$. According to the results, Reward management system leads to Employee commitment almost 34\%. This result of the study validates $\mathrm{H} 3$.

\subsubsection{Employee commitment and Employee motivation}

The regression results of the study confirm the significant positive relationship between Employee Commitment and Employee Motivation with $(\beta=0.699)$ and $(\mathrm{p}<0.01)$. According to these results, Employee Commitment leads to the Employee Motivation almost $70 \%$. This result of the study validates $\mathrm{H} 4$.

Table 4 summarizes the regression results of the study.

Table 4: Regression Results

\begin{tabular}{|l|l|l|l|l|l|l|}
\hline Hypothesis & Model variables & Estimate & S.E. & C.R. & P & Results \\
\hline H1 & $\begin{array}{l}\text { EC } \\
\text { ETP }\end{array}$ & 0.578 & 0.080 & 8.620 & $* * *$ & Supported \\
\hline H2 & $\begin{array}{l}\text { EC } \\
\text { JS }\end{array}$ & 0.378 & 0.101 & 4.964 & $* * *$ & Supported \\
\hline H3 & $\begin{array}{l}\text { EC } \\
\text { RMS }\end{array}$ & 0.339 & 0.093 & 4.380 & $* * *$ & Supported \\
\hline H4 & $\begin{array}{l}\text { EM } \\
\text { EC }\end{array}$ & 0.699 & 0.063 & 11.889 & $* * *$ & Supported \\
\hline
\end{tabular}




\section{Discussion}

In this study, we examined the relationship among Effective training program and Employee Commitment, Job satisfaction and Employee commitment, Reward Management System and Employee Commitment and Employee Commitment and Employee Motivation. For this purpose, we use convenience method for collecting data from employees working in different Organizations with the help of Questionnaire. Respondents' employee motivation, their affective training programs, job satisfaction, Reward Management system and Employee commitment are measured by multi element scales. The results got from the analysis allowed us to validate the established hypotheses and to understand the relationship between dissimilar variables of Employee Motivation Model. Now individually we discuss these finding and their implications in the following section.

Previous studies authorize the effect of Effective Training Programs on Employee Commitment.Commitment within the workstation typically results from the collaboration and the relationship that an employee has with an organization. The statistical analyses have exposed that the more training given to employees' the stronger employees' commitment to the organization. When an organization offers training to employees, the probabilities of better performance is improved. The human resource management experts should assimilate employee training, learning and development into HRM practices meant at getting a loyal workforce and also practices expected at increasing organizational performance (Fleetwood \& Hesketh, 2006; Huselid 1996). Also, access to training according to Brum (2010) can also play animportantcharacter into the level of commitment that is recognized. To be precise, employees are likely to place better value on training programs that are addedcommon and extremelyvalued by colleagues, supervisors, and managers. Bartlett (2001) reasons that organizations that are able to create an environment where training is supported and valued by employees will be able to achieve greater commitment results. The findings recommend that there are positive and significant relationship between Effective training programs and Employee Commitment.

Job satisfaction is often determined by how well the resulthappen or beat expectations and it represents several associated attitudes such as work itself, salary, advancementchances, administration and colleagues which are most vital characteristics of a job about which people have actual response (Luthans, 1998). Job satisfaction is so key that its absence often leads to fatigue and reduced Employee commitment (Moser, 1997). Dissatisfied employees are more likely to leave their jobs or be absent than satisfied employees (Rusbult et al, 1988). Highly devoted employees intend to stay within the organization and to work hard toward its goals (Luthans, McCaul, Dodd, 1985). These past studies show that there is positive relationship between job satisfaction and employee commitment.

Organizational reward division processes are one of the core tools for keeping and increasing work motivation (Erez \& Earley 1993). Organizations have great decision about the exactparts they can consider and reward when making decisions about highly appreciated resources such as wage raises or advancements, or making negative decisions such as those about firings. These studies shows that there is significant relationship exist between reward 
management system and employee commitment.

Stages of commitment may disturb how an employee values his/her work, and in turn may have an influence on how much they are willing to use their abilities to the full. Individuals who have a high organizational commitment rely on that "working at this company is significant to me", and they are more likely to agree with company's principles, feel a part of the company, be determined in tasks allocated, and catch work experiences meaningful for the good of the company along with for themselves, whileuninterested employees may not. Current research (Gosserand andDiefendorff, 2005; Meyer et al., 2004) has recommended that commitment is a powerful source of motivation to enhancement employees' vitality levels and to encourage them continue working even in tough situations. These researches propose that there is a significant and positive relationship between employee commitment and employee motivation.

\section{Limitations and Future Research}

Moreover these findings, the current study open numerous areas to be discovered in the future research.Convenience samples collected through the self-administrative questionnaire may limit the generalization of the study. In current study just used Questionnaire method, there is not used of Interview and Observation methods which limit the current study.

The current study was cross-sectional in nature and thus cause-and-effect relationships cannot be established definitely. Longitudinal designs to track employee Motivation over time are needed.

\section{References}

1. Aamodt, M.G. 2007. Industrial/Organisational Psychology: An Applied Approach. Belmont,CA: Wadsworth Cengage Learning.

2. Adeyemo, D.A. \& Aremu, A.O. (1999). Career commitment among secondary school teachers in Oyo state, Nigeria. The Role of biographical mediators.Nigerian Journal of Applied Psychology 5 (2), 184-194.

3. Alderfer, C. P. (1969). An empirical test of a new theory of human needs. Organizational Behavior and Human Performance, 4, 142-175.

4. Angle, H.L. \& Perry, J.L. 1981.An empirical assessment of organisational commit entandorganisational effectiveness', Administrative Science Quarterly, 26: 1-14.

5. Barber AE, Bretz RD, Jr. (2000). Compensation, attraction, and retention. In Rynes SL, Gerhart B (Eds.), Compensation in organizations: Current research and practice (pp. 32-60). San Francisco: Jossey-Bass.

6. Baron, R. A. (1983). Behaviour in organisations. New York: Allyn\& Bacon, Inc.

7. Baron, R. A. (1983). Behavior in organizations: Understanding and managing the human side of work. Boston: Allyn\& Bacon. 


\section{Macrothink}

Journal of Public Administration and Governance ISSN 2161-7104

8. Bartlett, K. (2001). The Relationship Between Training and Organizational Commitment: A Study in the Health Care Field. Human Resource Development Quarterly, 12(4), 335-352.

9. Brum, S. (2010). What Impact Does Training has on Employee Commitment and Employee Turnover.

10. Burke, B., Arkowitz, H., \& Dunn, C. (2002). The efficacy of motivational interviewing. In W. R. Miller \& S. Rollnick (Eds.), Motivational interviewing:Preparing people for change (2nd ed., pp. 217-250). New York: Guilford Press.

11. Chang, P.-Y., Hao, E., Patt, Y. N., and Chang, P. P. (1996). Using Predicated Execution to Improve the Performance of a Dynamically Scheduled Machine with Speculative Execution. International Journal of Parallel Programming, 24(3).

12. Cheramie, R.A., Sturman, M.C., Walsh, K. (2007) Executive career management: switchingorganizations and the boundaryless career, Journal of Vocational Behavior, 71: 359-374.

13. Chiaburu, D.S., and Tekleab, A.G. (2005). Individual and contextual influences on multiple dimensions oftraining effectiveness. Journal of European Industrial Training, Vol. 29 No. 8, pp. 604-26.

14. Diefendorff, J.M., Croyle, M. H., \& Gosserand, R.H. (2005). The dimensionality and antecedents of emotional labor strategies. Journal of VocationalBehavior, 66, 339-357.

15. Edward B. Roberts. Entrepreneurs in High Technology: Lessons from MIT and Beyond (New York: Oxford University Press, 1991).

16. Eisenberger, R., and Cameron, J. 1996. Detrimental effects of reward. American Psychologist, 51(11): 1153-1166.

17. Erez, M. (1993).Participation in goal setting - a motivational approach. In: E. Resenstein,and W.M. Lafferty (Eds.) International Handbook of Participation in Organization (pp.73-91). New-York: Oxford University Press.

18. Fleetwood, S., and Hesketh, A. (2006). High Performance Work Systems, Organisational Performance and(Lack of) Predictive Power. Journal of Critical Realism 5 (2), 228-250.

19. Gaertner K, Nollen S (1989), 'Career experiences, perceptions of employment practices, and psychological commitment to the organisation', Human Relations, Vol. 42, pp. 975-991.

20. Gellerman, Saul W. Motivation in the Real World: The Art of Getting Extra Effort from Everyone-Including Yourself. Dutton - New York 1992.

21. Hadjimanolis, A. 2000. An investigation of innovation antecedents in small firms in 
the context of a small developing country. $R \& D$ Management, 30(3): 235-245.

22. Hage, J., and Dewar, R. 1973. Elite values versus organizational structure in predictinginnovation. Administrative Science Quarterly, 18(3): 279-290.

23. Hunt, S.D., Chonko,L.B. \& Wood, V.R. 1985 Organisational commitment marketing', Journal of Marketing, 49: 112-126.

24. Janssen, O. 2000. Job demands, perceptions of effort-reward fairness and innovative work behaviour. Journal of Occupational and Organisational Psychology, 73(3): 287-302.

25. Kotze, K. \& Roodt, G. 2005. 'Factors that affect the retention of managerial and specialist staff: An exploratory study of an employee commitment model', South African Journalof Human Resource Management, 3(2): 48-55.

26. Lang, D. L. (1992). Organisational culture and commitment. Human Resource Development Quarterly, 3(2)191-6.

27. Lindner, J. R. (1998), “Understanding Employee Motivation”, Journal of Extension 36(3).

28. Locke, E. (1976). The nature and causes of job satisfaction. In M. D. Dunnette (Ed.). Handbook of industrial and organizational psychology (1297-1349). Chicago: Rand McNally.

29. Luthans, F. (1998). OrganisationalBehaviour. 8th ed. Boston: Irwin McGraw-Hill

30. Luthans, F. (1998). OrganisationalBehaviour. 8th ed. Boston: Irwin McGraw-Hill.McCormick and J. Tifflin. 1979. Industrial Psychology; New York: George, Allen and Unwin.

31. Luthans, Fred, Harriette S. McCaul, Nancy G. Dodd (1985). Organizational Commitment: A Comparison of American, Japanese, and Korean Employees, The Academy of Management Journal, 28(1), pp.213-219.

32. Meyer, J. P., Becker, T. E., \&Vandenberghe, C. (2004). Employee commitment and motivation: A conceptual analysis and integrativemodel. Journal of Applied Psychology, 89, 991-1007.

33. Moorhead, G., \& Griffin, R. W. 1998. Organizational Behavior: Managing people and organizations (5th ed.). Boston, MA: Houghton Mifflin.

34. Moser, K. (1997). Commitment in organizations. Psychologies 41 (4), 160-170.

35. Mowday, R., Steers, R. \& Porter, L. 1979. 'The measurement of organizational commitment', Journal of Vocational Behaviour, 14: 224-247.

36. Mumford, M.D. 2000. Managing Creative People: Strategies and tactics for innovation. Human Resource Management Review, 10(3): 313-351. 
37. Reichers, Arnon E. (1985). “A Review and Reconceptualization of Organizational Commitment". Academy of Management Review 10 (3): 465-476.

38. Reio, G, T. \&Callahon, J. L. (2004). Affect, Curiosity, and socialization-related Learning; a path analysis of antecedents to job performance, Journal of Business and Psychology, Vol.19, pp3-22.

39. Riggio, R.E. 2009. Introduction to Industrial/Organisational Psychology. London: Pearson.

40. Rothwell, R., 1992. Successful Industrial Innovation: Critical Success Factors for the 1990’s. R\&D Management, 22 / 3, 221-239.

41. Rusbult, C. E., Farrell, D., Rogers, G. and Mainous, A. G. III (1988). 'Impact of exchange variables on exit, voice, loyalty, and neglect: an integrative model of responses to declining job satisfaction'. Academy of Management Journal, 31, 599-627.

42. Scott, S. G., \& Bruce, R. A. (1994). Determinates of innovative behavior: A path dual innovation in the workplace. Academy of Management Journal, 137, 580-607.

43. Van Knippenberg, D. (2000). Work motivation and performance: A social identity perspective. Applied Psychology: AnInternational Review, 49, 357-371.

44. Vroom, V. H. ( ! 964). Work and motivation. New York: Wiley. 